\title{
THE EFFECT OF THE PERCEPTION OF RETAIL INNOVATION BY CONSUMERS ON SATISFACTION AND BEHAVIORAL INTENTIONS: AN EMPIRICAL STUDY
}

\author{
Cevahir UZKURT \\ Eskisehir Osmangazi University, Turkey \\ Hasan ORSOY \\ Migros Turk Co., Turkey
}

\begin{abstract}
In recent years, there has been growing a particular interest in the innovation concept, diffusion of innovation and innovation management among both business researchers and practitioners. Despite this considerable body of growing research, the relationship between the perception of innovation by consumers and behavioral intentions and satisfaction has not still been investigated. However it is very important to determine how consumers perceive innovation than firms offering innovation to them. It must also be noticed that this side of the subject has a particular importance in the retailing industry due to the developments occurring in this industry in recent years resulting with the hard competition conditions; thus, the importance of innovation for competitive advantage for the firms in this particular market should definitely be underlined.
\end{abstract}

The purpose of this paper is to explore the relationship between the perception of innovation by consumers and behavioral intentions and satisfaction. Data for the study were collected through a survey from the customers of a supermarket in the city of EskisehirTurkey, namely Tansas, which is one of the retailing formats of Migros Turk Co., the leading company of Turkey in the food retailing industry.

The results indicate that consumer satisfaction affected by the perception of innovation leads to behavioral intentions. The results also showed that even if the consumers' perception of both innovative services and common services affect behavioral intentions and satisfaction, the correlation of innovative services is significantly higher than the common services; that is, the perception of innovation has much more influence on behavioral intentions and satisfaction than that of the common services.

This study provides empirical information for international marketers about the relationship between the perception of innovation by consumers and behavioral intentions and satisfaction. This paper contributes to the growing body of innovation management and adoption of innovation.

\section{INTRODUCTION}

In recent years, the innovation concept has inevitably been one of the most attention-drawn subjects by both business researchers and practitioners due to its wide acceptance as a strong predictor and determinant of competitive advantage for firms in the market (Bass, 1969; Rogers, 1995; Manning et al., 1995; Stanton and Stanton, 2002; Im et al., 2003; Lassar et al., 2005; Singh, 2006). Most of the previous studies on this subject have focused on to the organizational side of the innovation concept (Schumpeter, 1939; Burns and Stalker, 1961; Hull and Hage, 1982; Kanter, 1988; Hamel and Prahalad, 1994) while some others studied the classification of consumers based on the speed of adoption of innovation (Bass, 1969; Rogers and Shoemaker, 1971; Rogers, 1995; Kotler, 2003). However, without declining the importance of the firms' offers about new products and services, the perception of these by the consumers should take at least the same attention since the new products and services offered by the firms would gain importance only if the adoption by the consumers should be maintained. For this reason, how consumers perceive new products and services occurs to be an important subject; thus, one of the main purposes of this study is to explore how innovation is perceived by consumers. Another important concept for the competitive firms is customer satisfaction as it has become one of the most effective instruments especially for service firms to increase customer loyalty and thereafter, their market performance (Jones and Sasser, 1995; Oliver, 1999). 
Most of the previous studies about the customer satisfaction concept imply that customer satisfaction is a strong and significant determinant of customers' behavioral intentions (Woodruff, 1997; Eggert and Ulaga, 2002; Sweeney et al. 1999, Brady and Robertson, 1999; Cronin et al., 1997). As a result, considering innovations offered by the firms to the consumers to contain new values for them, the perception of innovations -as a value for consumershas strong effects on satisfaction and behavioral intentions (Eggert and Ulaga, 2002).

Retailing, nowadays, is one of the most competitive markets worldwide and the firms are struggling hard to maintain customer satisfaction and loyalty in order to obtain competitive advantage (Sirohi et al., 1998). By that means, new products and services are used as important instruments even though they contain certain risks (Littler and Melanthiou, 2006). As a consequence, this study aims to explore how retail innovations are perceived by consumers as well as to examine the effects of this perception on their satisfaction and behavioral intentions.

A structural model has been developed in this study taking the findings of the previous studies into consideration and this model is analyzed and tested by the data obtained from a survey applied to the customers of a supermarket. With the model developed, it is proposed that the perception of innovation by the consumers leads to satisfaction which, in turn, leads to behavioral intentions. This model underlines the indirect effect of the perception of innovation on behavioral intentions via customer satisfaction rather than a direct effect, which is also explained in this study with an alternative model and the comparison between the two models were made.

As the second purpose of the study, the effects of the perception of both retail innovations and common retail services are compared with each other by means of customer satisfaction and behavioral intentions resulting with the higher influence of the perception of innovation rather than the common services.

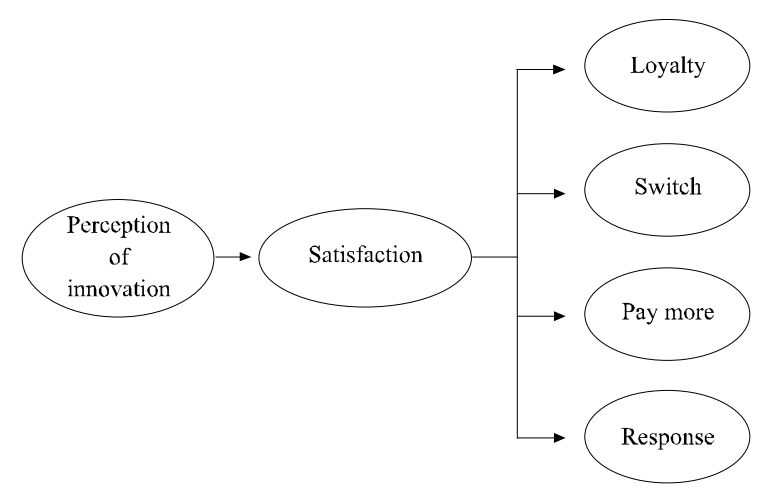

Figure 1. Research model: Mediated model

\section{BACKGROUND}

Each of the components of the model - perception of innovation, customer satisfaction, and behavioral intentions - will be discussed in turn. This review will provide the basis for both the methodological approach taken and measurement used to test the model.

\section{Innovation and Adoption of Innovations}

Innovation is described as any good, service, or idea that is perceived by someone as new (Kotler, 2003: 376). According to Rogers (1995), innovation takes time to spread through the social system and innovation diffusion process is a new idea's becoming widespread from its source of invention or creation to its ultimate users or adopters. Adopters of new products have been observed to move through five stages: Awareness, interest, evaluation, trial, and adoption (Rogers, 1995; Kotler, 2003: 376).

Bass (1969), defined the first buyers of new products as pioneers and the subsequent buyers as imitators and indicated that the buying decisions of the imitators about new products were shaped by the number of pioneers. Rogers (1995), on the other hand, categorized the users of new products as innovators, early adopters, early majority, late majority, and laggards, based on the timeline due to time of adoption of innovations.

Innovation-diffusion subject has been studied a lot by the researchers over the years and four dominating themes were formed, such as: the mathematical modeling of the process at the aggregate level (Fourt and Woodlock, 1960; Mansfield, 1961; Bass, 1969), modeling adoption at the individual level (Chatterjee and Eliashberg, 1990), the identification of characteristics of different adopter groups (Rogers, 1995) and the impact of marketing and other variables on the diffusion and adoption processes (Mahajan et al., 1990; Jain, 1992; Bass et al., 1994). However, few of these studies deal with the area of spatial diffusion of innovations which can be considered as an important but underdeveloped area of the adoption and diffusion literature. Its importance comes from the fact that the great majority of innovations are launched into geographically defined markets, in specific local areas, regions or countries and understanding the processes by which consumers are influenced to adopt new innovations spatially can be much more successful in launching new products and can make much better use of firms' resources while doing so (Allaway and Berkowitz, 2005). 
Two of the studies mentioned above (Bass, 1969; Rogers, 1995) laid a foundation for a majority of further studies about the adoption of innovation (Midgley and Dowling, 1978; Goldsmith and Hofacker, 1991; Fell et al., 2003; Tsu Wee, 2003). The consumers who adopt innovations are classified according to their individual psychographic and demographic factors in these studies whereas the effects of personal and cultural values of consumers on adoption of innovations are studied in some others, such as: the relationship between the adoption of innovations and culture by Slowikowski and Jarrat, (1997), Steenkamp et al., (1999); consumers' customs by Green and Langeard, (1975); personal characteristics by Lassar et al., (2005), Singh, (2006); and interactions between individuals by Clark and Goldsmith, (2006). In the findings of these studies which focus on personal and demographic effects on the adoption of innovation; young, highlyeducated consumers with high income and social status generally tend to adopt innovations more likely than the others.

Besides the consumer-sided factors affecting the process of adoption of new products and services, some product-sided factors may also be mentioned. Referring to the previous studies, these factors can be listed mainly as: information on the product by Lai, (1991); price and promotions by Kalish, (1985); perceived risk by Hirunyawipada and Paswan, (2006); and convenience to use by Lin, (2006). Rogers and Shoemaker, (1971: 22-23), on the other hand, stated the product-sided factors affecting the speed of adoption of new products and services as: relative advantage, compatibility, complexity, divisibility and communicability.

The early research on innovation concept focused on to the organization's ability to respond and adapt to external and/or internal changes (Burns and Stalker, 1961; Hull and Hage; 1982). Subsequent studies on innovation tend to distinguish between types of innovation. By that means, organization's ability to promote the two types of innovation, namely process and product innovation was emphasized (Kanter, 1988) but yet been argued to be no longer sufficient, resulting with the introduction of a third type of innovation in the literature: strategy (business concept) innovation. This type of innovation stresses the growing need for today's organizations to proactively address challenges of the future by undertaking radical innovation that will transform their environments and the marketplace (Hamel and Prahalad, 1994; Hamel, 1996).

The three types of innovation, namely process; product/service; and strategy/business concept, mentioned above may vary from incremental to radical and from sustaining to discontinuous which constitute the levels of innovation. By that means, innovation can be said to be no longer restricted to the process of creating something new from beginning to end but can include the capacity to quickly adopt externally created innovations that may be of benefit to the organization (Baker, 2002).

Innovations, ranging from incremental to radical, primarily focused this distinction on the extent of newness. An innovation can be new within a particular context or new in terms of the overall marketplace of ideas, or, it can be a new way of an old theme or a radically novel idea. This distinction, on the other hand, does not exactly differentiate between newness and impact because in terms of impact, the effect of an innovation can range from: (1) contributing to fairly small improvements to products or to the way things are done, (2) causing a fundamental transformation in the resulting products or services and/or the process technology of an entire industry, or (3) transforming the market place and/or the economy as a whole (Baker, 2002). Furthermore, the attributes of newness and impact were also disentangled, as radically new innovations do not always have a significant impact thus change from sustaining versus discontinuous innovations (Christensen, 1997). Sustaining innovations improve the performance of established products or services while discontinuous innovations bring to market very different products or services that typically undermine established products and services in the particular market sector.

Process innovation became an important topic with the rise of the quality and continuous improvement movements and furthermore with the more recent attention directed at change management, organizational learning and knowledge management. In the case of product/service innovation, its incremental side is oriented towards improving the features and functionality of existing products and services while its radical side is oriented towards creating wholly new products and/or services. Product life cycles, in particular, have become shorter and shorter, causing business survival to depend on new product development and, increasingly, on the speed of innovation in order to develop and bring new products to market faster than the competition (Jonach and Sommerlatte, 1999). Strategy or business concept innovation, above all, deals to redefine market space and to redraw industry boundaries.

Existence of certain driving forces of innovation was 
mentioned in the literature. According to Baker (2002), the primary drivers of innovation include: Financial pressures to decrease costs and increase efficiency, increased competition, shorter product life cycles, value migration, stricter regulations, industry and community needs for sustainable development, increased demand for accountability, community and social expectations and pressures (giving back to the community, doing good, etc.), demographic, social, and market changes, rising customer expectations regarding service and quality, greater availability of potentially useful new technologies coupled with the need to keep up or exceed the competition in applying these new technologies, and the changing economy.

Although cost reduction has been a major driver of innovation, other drivers, like regulatory drivers, have become more important in the last several decades. In addition, companies increasingly feel they must promote their image and this has become a major driver of environmental and sustainable development innovations. A good image can help promote both customer loyalty and a company's growth strategy, which, in our case appears to be driven by service innovations for the companies in the retailing industry.

\section{Retail Innovation and Adoption of Retail Innovations}

From the 1920 's to the 1970 's, food retailing underwent a profound evolution in the United States. Through industrialization and urbanization, consumers increasingly depended on markets for their food needs and increasingly bought packaged foods. A new type of food retailer (supermarkets - large full-line, self serve stores) gained considerable market share at the expense of traditional, small, limited-line clerk-service stores. These supermarkets used economies of scale and market power, along with inventory and merchandising technologies to compete for business through price, assortment, advertising, reliability and customer service (Hagen 2002). Regarding this evolution as the modernization of food retailing, modernization has been seen to occur in other advanced economies, and from the 1980's to the present, many examples of rapid modernization of food retailing in a number of developing countries, as in the case of Turkey where this evaluation have accelerated in the 1990 's as both national and foreign major companies began to be active in the market (Varinli, 2005: vi). With the effect of the consolidations recently occurred in this sector, Migros-Tansas, BIM, Metro Cash \& Carry, Tesco-Kipa, Carrefour, and Real have become the major players of the Turkish retail industry and the total market share of hyper, chain and supermarkets has reached to $\% 33,1$ with 5545 points of sales in 2005 (Arasta Magazine, 2006: 62-63).

The modernization of food retailing can be regarded as technical change that is based on innovations that are both technological and institutional in nature. Examples of the former are scanning cash registers, packaging technology, inventory management software, and market research. Institutional innovations include self-service, assortment of products, number of items stocked, use of retailer (rather than manufacturer) labeling, demand development, and development of distribution centers. Because the two classes of innovation are inter-related (e.g., the institution of self-service would not be possible without packaging technology), they, in combination, can be referred as retail innovation (Hagen, 2002).

According to Vernon (1966), retail innovations can be expected to arise endogenously from demand conditions, as a demand-pull phenomenon and innovations realized create further demand, leading to further innovations. Convenience is not the only positive outcome of retail innovation. According to Sternquist (1998), customers of all income groups appreciate self serve in that it enables holding and inspecting the merchandise. Also, many innovations (e.g. mass merchandising, inventory control technology, self-service) decrease costs. Those savings can benefit lower income consumers in developing economies (Galbraith and Holton, 1955).

In the previous studies, retail innovations were classified and defined by means of different dimensions. According to Davies (1998), innovations in the retail sector could be evaluated in terms of many different facets whereas concentrated mainly on four areas: diversification, particularly in the food retail industry; automation, across all sectors of retailing but particularly in the context of electronic shopping; personalization, in the sense of retailers targeting their customers more closely; and conceptualization, in terms of new store formats and new product development. Having stated innovation's great importance in retailing, McCarthy (2005) simply defined the two important areas of retail innovation as inventory control and electronic commerce. Staib (2004), meanwhile, pointed out some different aspects and consequences of retail innovation such as: selfeverything; guilt-free shopping, pop-up retailing, RFID (radio frequency identification) and wireless technology; mass customization; and data mining and CRM (customer relationship management). 
Rosenberger et al. (2001), distinguished the types of new retail innovation as minor retail mix changes, brand extensions in an allied field, store-within-astore concepts, makeovers (e.g. updates/renovations), brand extensions in an unrelated field, combinations (of other formats), and radical new formats. In their study where the 4D model was developed and introduced, Hertog and Brouwer (2000), defined the four dimensions of innovations in retailing as: new service concept, new client interface, new service delivery system, and technological options; and distinguished patterns of retailing innovation as: supplier dominated innovation (e.g. scanning registers), innovation in services (e.g. new shop formulas), client led innovation (e.g. home deliveries), innovation through services (e.g. new ICT systems for client profiling), and paradigmatic innovations (e.g. ecommerce). As can be seen, researchers studied this particular subject with very different approaches and from very different point of views.

In the case of drivers of innovation in retailing, Hertog and Brouwer (2000), underlined the following driving forces: changing consumer behavior; increased number of locations from where and times at which consumers purchase; non store retailing \& new retailers; diversification, parallellisation and additional service elements; experiences and entertainment; consumer profiling and logistics (towards suppliers and towards consumers); and role of consumers. Changes in consumer behavior leaded to a new concept recently studied a lot by researchers: the new consumer. As Hertog and Brouwer (2000) stated, looking at how consumer behavior changes might help to map out the relevant environment for retailers and the transformation from acquiring to experiencing is probably one of the most important changes taking place, forcing retailers to step forward with new services, products, and service add-ons. Consumption concept, then, is not only consisted of functional benefits but is an activity with different sides that might be felt and lived by experience; such as fantasies, feelings and fun (Torlak and Altunisik, 2007: 45-66). Thus, the new consumer concept is one of the most critical points to be considered while planning and realizing retail innovations.

What causes innovation in services was described as a new or considerably changed service approach; differentiation in the presentation or distribution of the service; and the usage of new technologies in the presentation of the service; all requiring technological and organizational capabilities for the firms (Elci, 2006). In the case of consumer adoption of retail services, the extent to which the consumer actively engages in the process is likely to depend on the level of involvement (Zaichowsky, 1985) with the service category of the innovation. According to Littler and Melanthiou (2006), in constructing her/his perception of the innovation, during the early stages of the life of the innovation the adopter will be handicapped by inadequate, perhaps contradictory, information, while personal or observed experience with the innovation will naturally be limited and over time consumers will learn about the innovation through personal and vicarious experience.

Innovation, in this study, is taken as the service improvements and new add-ons realized in Tansas format of Migros Turk Co., in terms of consumer rights. Some items of regular consumer rights were moved one-step-forward with these service-based applications which were declared as "Incredible Consumer Rights" by the company. There are eight statements about this concept five of which were taken into measurement in this study.

\section{Satisfaction and Behavioral Intentions}

Customer satisfaction, recently, has become one of the most effective instruments especially for service firms to increase their market performance via customer loyalty (Jones and Sasser, 1995; Oliver, 1999). Customer satisfaction, in general terms, is defined as the concept of the ratio between the expectations before-purchase and the situation after-purchase (Parasuraman et al., 1988; Westbrook and Oliver, 1991; Eggert and Ulaga, 2002). According to this definition; if the performance of the products and services are equal to or above the customer's expectations, satisfaction shall be fulfilled. On the contrary; if the performance of the products and services are below customer's expectations, unsatisfaction occurs (Parasuraman et al., 1988; Woodruff, 1997).

Achieving customer satisfaction is the primary goal for most of the service firms today (Jones and Sasser, 1995). Increasing customer satisfaction and customer retention leads to improved profits, positive word-ofmouth, and lower marketing expenditures (Reicheld, 1996; Heskett et al., 1997). Typically, customer satisfaction is monitored on an ongoing basis using Likert-type scales that measure customers' level of satisfaction based on their last service encounter (Peterson and Wilson, 1992; Heskett et al., 1997), as done in this study as well. 
There has been considerable debate as to whether customer satisfaction is an attitude or a relatively transient consumption-specific construct, or whether it is an outcome or an evaluation (Yi, 1990). A further debate has considered whether service quality is a cause of satisfaction (Cronin and Taylor, 1992; Parasuraman et al., 1985) or a consequence of satisfaction (Bitner, 1990; Bolton and Drew, 1991). Westbrook and Oliver (1991) stated that satisfaction is, in part, the totality of the purchase situation relative to expectations.

Although the relationship between customer satisfaction and future intentions has been identified (Oliver 1980; Bearden and Teel, 1983), limited empirical evidence appears to exist concerning the relationship between future intentions and their potential determinants; service quality dimensions and perceived value (Bolton and Drew, 1991). It is not clear whether future intentions and customer satisfaction are driven by the same set of factors. The uncertainty stems from the basic notion that customer satisfaction is a necessary but not a sufficient condition for future intentions. It has been proposed that customers' assessments of service value influence purchase intentions and behavior. Service quality and satisfaction are distinct constructs and there is a casual relationship between the two; as the perceptions of service quality affect feelings of satisfaction which, in turn, influence future purchase behavior (Hurley and Estelami, 1991).

The importance of determining the relationship between the drivers of customer satisfaction and the linkages, if any, between these drivers, customer satisfaction and future intentions is again related to improving the effectiveness of decision making. Understanding how customers evaluate their services and the consequences of these evaluations by means of satisfaction and future intentions, better allocation of resources on competitive instruments, like the innovations the firms plan to offer, might be realized by the firms to increase customer loyalty and their market performance.

In the case of behavioral intentions, when customers' perceptions of service quality are high, the behavioral intentions are favorable, which strengthens their relationship with the organization. On the other hand, when service quality assessments are low, the customers' behavioral intentions are unfavorable and the corresponding relationships with the company deteriorate (Alexandris et al., 2002). Favorable behavioral intentions includes elements such as saying positive things and recommending the service to others, paying a price premium to the company, and expressing cognitive loyalty to the organization (Zeithaml et al., 1996). Cognitive loyalty has operationalized as the service that first comes to one's mind when making a purchase decision and the service, which was a customer's first choice among alternatives (Pritchard et al., 1992; Bloemer et al., 1999). Zeithaml et al. (1996) also suggested that unfavorable behaviors included voice responses, private responses, and thirdparty responses. All these elements of behavioral intentions lead to four dimensions such as: word-ofmouth communications, purchase intentions, price sensitivity, and complaining behavior (Alexandris et al., 2002). In terms of overall service quality perceptions, willingness to recommend was positively related (Boulding et al., 1993), switching and complaining behavior were negatively related (Kelley et al., 1993), price sensitivity was positively related (Zeithaml et al., 1996), and purchase intentions, customer loyalty and willingness to pay more money were directly and positively related (Baker and Crompton, 2000). However, contradictory results were also reported; as Cronin and Taylor (1992) stated nonsignificant relationships, while Boulding et al. (1993) stated significant and positive ones. In a recent study, Bloemer et al. (1999) provided evidence that the patterns of relationships were not universal, but they were industry based

Due to the fact that customer satisfaction is a strong and significant determinant of customers' behavioral intentions (Woodruff, 1997; Eggert and Ulaga, 2002; Sweeney et al. 1999, Brady and Robertson, 1999; Cronin et al., 1997), and considering innovations offered by the firms to the customers to contain new values for them, the perception of innovations -as a value for customers- has a strong and direct effect on satisfaction and behavioral intentions (Eggert and Ulaga, 2002).

The research model will test the following hypotheses:

H1: Perception of innovation by the customers will be positively associated with customer satisfaction.

$\mathrm{H} 2$ : Customer satisfaction will be positively associated with loyalty.

H3: Customer satisfaction will be negatively associated with switch.

H4: Customer satisfaction will be positively associated with pay more. 
H4: Customer satisfaction will be positively associated with pay more.

H5: Customer satisfaction will be negatively associated with response.

\section{METHODOLOGY}

\section{Sample and Data Collection}

Data for study were gathered via a survey among customers of a Tansas supermarket in the city of Eskisehir. Data collection occurred over a two week period and has been completed between the hours of 10 a.m. and 8 p.m. during each day. A total of 321 surveys were accepted as usable for the study. Regarding a monthly customer penetration of about 100.000 through this store, the sample size was calculated -with a 95 percent confidence level and 5 percentage points of error- as 321 (Zikmund, 1994: 497). The surveys were applied by 5 people to whom the necessary education had been given about the survey process before and these people applied the survey face-to-face to customers who have willingness to response.

\section{Measures}

The survey employed multi-item scales to measure the model constructs. Survey form used for the research consists of three parts. The first part contains 5 statements about retail service innovations to measure the perception of innovation by customers, listed below:

1 .Unconditional return warranty for grocery products bought from Tansas in case of unsatisfaction, even partly consumed.

2. In case of out-of-stock for a product in promotion which Tansas pronounces, an alternative product with equal or high quality is sold with the discount price.

3. When a product out-of-date is found in the store by a customer, a newer one is given her/him free of charge.

4. If the price of a product printed in the shelf-label is different than that of the scanning cash register, the lower price is valid.

5. If there is a cue in front of a scanning cash register while another one is closed, it will be opened in maximum three minutes when the workers are informed.
The 2 nd, 3rd, and 5 th of the innovations above were accepted as radical while the 1 st and 4th as incremental because the subsequent two were the improvements of existing consumer rights and after-purchase services while the other three occurred to be new add-ons introduced to the sector for the first time as they were not available and applied in the competitors. The items used in the scale were anchored at excellent (1) and poor (4).

Six statements concerning common retail services that can be called as non innovative- were also available in the first part of the survey and listed below:

1. Assistance of store workers to the customers about their problems and questions.

2. Existence of signboards in the store to direct the customers to the departments.

3. Availability of certain physical conditions in the store; like heating-cooling, air-conditioning and illumination.

4. Existence of express scanning cash registers for paying convenience and speed for purchases below five items.

5. Existence of carrying vehicles and hand baskets with different sizes to help customers for carrying different amount of products they buy.

6. Hygiene applications in service departments (e.g. meat \& poultry, delicatessen, and fruit \& vegetable).

The items used in the scale were anchored at excellent (1) and poor (4).

The second part of the survey form contains questions that ask the respondents to rate behavioral intentions (loyalty, switch, pay more, external response and internal response) and satisfaction level. These factors were selected from previous studies Zeithaml et al. (1996), Oliver and Swan (1989). 
Table 1. Construct operationalization and measurement quality

\begin{tabular}{|c|c|c|c|}
\hline Constructs & Items & Cronbach alpha & $A V E$ \\
\hline $\begin{array}{l}\text { Customer } \\
\text { satisfaction }\end{array}$ & $\begin{array}{l}\text { 1.I am very satisfied with the services of Tansas. } \\
\text { 2.I think that Tansas is very ideal supermarket than its } \\
\text { competitors. } \\
\text { 3.I think that I did the right thing when I decided to buy from Tansas. } \\
\text { 4.It is a pleasure to have a purchasing relationship with } \\
\text { Tansas }\end{array}$ & 0.86 & 0.73 \\
\hline Loyalty & $\begin{array}{l}\text { 5.Say positive things about Tansas to other people } \\
\text { 6.Recommend Tansas to someone who seeks your advice } \\
\text { 7.Encourage friends and relatives to purchase from Tansas } \\
\text { 8.Consider Tansas your first choice to buy retail services } \\
\text { 9.Purchase more from Tansas in the next few years }\end{array}$ & 0.84 & 0.82 \\
\hline Switch & $\begin{array}{l}\text { 10.Purchase less from Tansas in the next few years* } \\
\text { 11.Take some of your purchasing to a competitor that offers } \\
\text { better prices* }\end{array}$ & 0.72 & 0.75 \\
\hline Pay more & $\begin{array}{l}\text { 12.Continue to purchase from Tansas if its prices increase } \\
\text { somewhat } \\
\text { 13.Pay higher price than competitors charge for the benefits } \\
\text { you currently receive from Tansas }\end{array}$ & 0.76 & 0.80 \\
\hline Response & $\begin{array}{l}\text { 14.Switch to a competitor if you experience a problem with } \\
\text { Tansas' services } \\
\text { 15.Complain to other customers if you experience a problem } \\
\text { with Tansas' services }\end{array}$ & 0.69 & 0.77 \\
\hline
\end{tabular}

\section{Data Analysis and Results}

Of the 321 respondents, 53 per cent are male; a large proportion has completed high school and University study (93 per cent). Most of the sample consists of young people between 40 years old and younger $(70$ per cent). The largest proportion of sample had low income 300-1200 YTL.- (57 per cent).

To refine our measurement model before testing the structural components of the research, Gerbing and Anderson's (1988) recommendations were followed. Reliability, convergent validity, and discriminant validity of the measurements were assessed. The items were examined first by item-to-total correlations. Items with low correlation were deleted. The remaining items were subjected to exploratory and confirmatory factor analysis to assess validity. In the process of purifying the scales, two items measuring behavioral intentions were dropped. The construct reliabilities, average variance extracted for each of the construct employed are reported in Table 1. As the table shows the construct reliabilities for all the constructs above are above the minimum of 0.70 recommended by Nunnally (1978). Average variance-extracted estimates greater than 0.5 for each the constructs, indicates convergent validity among items measuring the construct (Bagozzi and Yi. 1988; Fornell and Larcker 1981). With regard to discriminant validity, we employed the test proposed by Fornell and Larcker (1981). In this test, it is concluded that constructs are different if the average variance extracted (AVE) for one's constructs is greater than their shared variance. That is, a construct is empirically distinct if the average variance explained by that construct's items is greater than the construct's shared variance with every other construct. For example, loyalty demonstrates discriminant validity because its average variance extracted $(0.82)$ is greater than the square of its 
correlations with satisfaction $(0.822=0.67)$; switch $(-$ $0.422=0,17)$; pay more $(0.422=0,17)$; and response $(-$ $0.352=0.12$ ). Analysis of the data provides strong evidence of discriminant validity with the average variance of all constructs being greater than the construct's shared variance with every other construct. After having shown that the measurement models are consistent with the empirical data, the substantive relationships between perception of innovations, customer satisfaction and behavioral intentions were tested using the statistical package AMOS 5.0.

Perception of retail innovation is estimated to have a strongly positive and highly significant impact on customer satisfaction in the mediated model (Figure 2). Satisfaction itself has a strongly positive and highly significant impact on loyalty and pay more and negative and significant impact on switch and response. The mediated model has a very good fit $(\mathrm{X} 2 / \mathrm{df}=3.2$; GFI $=0.91 ; \mathrm{AGFI}=0.84 ; \mathrm{CFI}=0.93 ; \mathrm{NFI}=0.92 ; \mathrm{RMSEA}$ $=0.083$ ) (Table 2). Adding direct relationships between perception of innovation and behavioral intentions did not improve the fit significantly. Therefore, the results show that customer satisfaction affected by the perception of innovation by customers leads to behavioral intentions. The results occurred to be consistent with the results of previous researches (Eggert and Ulaga, 2002; McDougall and Levesque, 2000).
Tablo 2. Global fit indices for both mediated model and direct model

\begin{tabular}{|l|c|c|}
\hline Global fit index & $\begin{array}{r}\text { Research model: } \\
\text { Mediated model }\end{array}$ & $\begin{array}{c}\text { Alternative model: } \\
\text { Direct model }\end{array}$ \\
\hline $\mathrm{X}^{2 / \mathrm{df}(<5)}$ & 3.2 & 5.4 \\
\hline GFI $(>0,90)$ & 0.91 & 0.59 \\
\hline AGFI $(>0,85)$ & 0.84 & 0.65 \\
\hline CFI $(>0,90)$ & 0.93 & 0.70 \\
\hline NFI $(>0,90)$ & 0.92 & 0.74 \\
\hline RMSEA $(<0,10)$ & 0.083 & 0.117 \\
\hline
\end{tabular}

In the alternative model (direct model), perception of retail innovation is supposed to have a direct impact on the behavioral intentions. Here perception of innovation by customers is estimated to have a strongly positive impact on loyalty and poor positive impact on pay more. It also has not significant impact on response (Figure 3). Besides, the alternative model performs significantly lower than the mediated model $\left(\mathrm{X}^{2} / \mathrm{df}=5.4 ; \mathrm{GFI}=0.59 ; \mathrm{AGFI}=0.65 ; \mathrm{CFI}=0.0 .70\right.$; $\mathrm{NFI}=0.0 .74 ; \mathrm{RMSEA}=0.117)($ Table 2$)$. Therefore the mediated model clearly occurs to be preferred over the direct model. Table 2 presents a comparison of global fit indices. All the hypotheses of the research were supported.

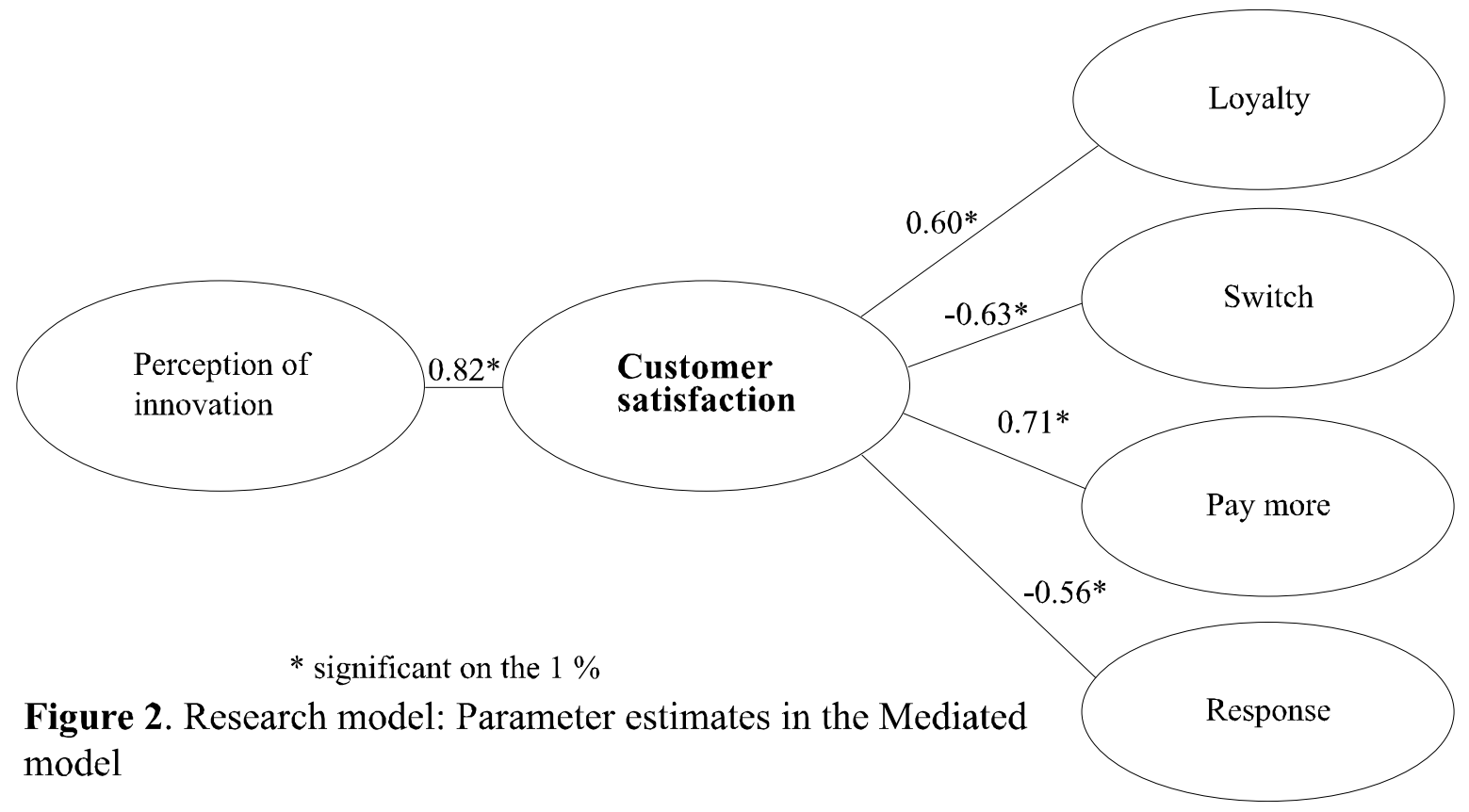




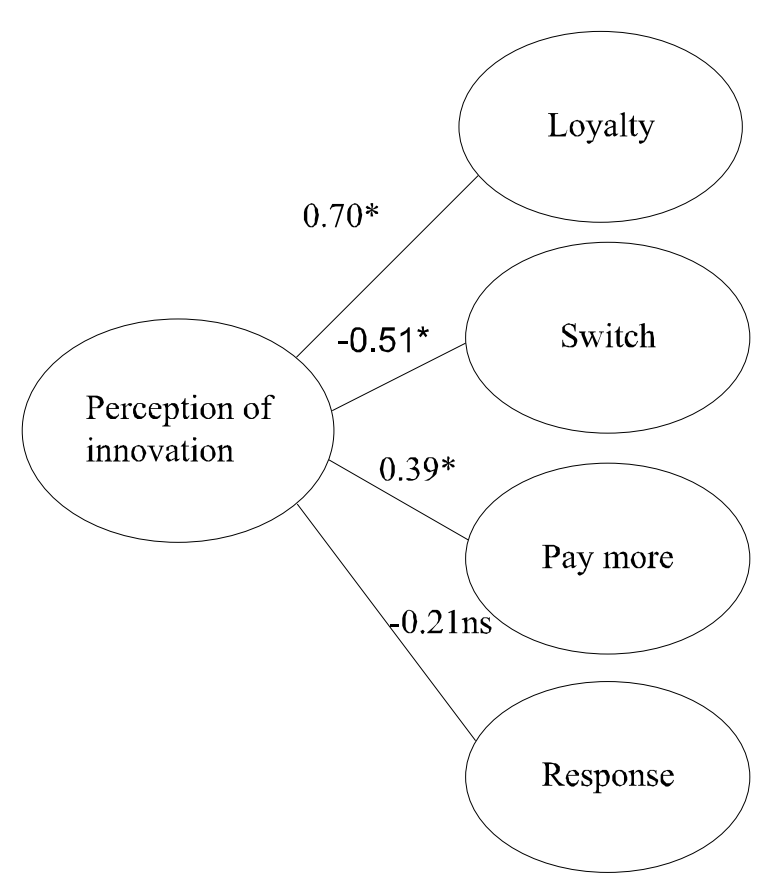

* significant on the $1 \%$ level, ns: not significant

\section{Figure 3. Alternative model: Direct model}

Furthermore, direct model is used to test the impact of the perception of common services (non innovative) by customers on behavioral intentions and satisfaction. The results also showed that mediated model with perception of innovation have a significantly better fit and correlations than the mediated model with perception of common services.

\section{CONCLUSION}

Retailing requires a considerable understanding of the changing behavior of consumers. As retailing can be characterized as the 'art of seducing' consumers to buy, knowledge is required of what triggers people to buy, how to market new products and services, how to make sure people find it attractive to spend time in the store and become loyal customers. Being able to transform knowledge of human behavior in concepts and formulas for end users is one of the key drivers of innovation in retailing (Hertog and Brouwer, 2000).

Realizing innovations in retailing has long been one of the most important instruments for the firms in this sector to have competitive advantage by means of obtaining and/or increasing customer loyalty and their market performance; and identifying how consumers perceive innovation -rather than the firms' offers- has a significant and certain importance, in relation. This paper indicates that customer satisfaction affected by the perception of innovation leads to behavioral intentions rather than the direct effect of the perception of innovation on the behavioral intentions. The concepts of perception of innovation and customer satisfaction do not substitute but complement each other.

The results also showed that even if the perception of both innovative services and common services by customers affect behavioral intentions and satisfaction, the correlation of innovative services is higher than the common services, that is, the perception of innovation has much more influence on behavioral intentions and satisfaction than that of the common services.

Regarding these results, it is clear that the firms in the retailing sector may obtain considerable competitive advantage if they allocate the necessary resources to realize innovations -especially in the services- besides the other instruments.

A limitation to state for this study is that this study was based on a cross-sectional sample to ensure a generalization for the results, but the survey was applied in one single country and should be extended to respondents from different countries to allow for cross-country validation. Besides, the innovations chosen were all service-based so the perception of other dimensions of innovation (e.g. technological) represents a potential for further research in this area.

This study provides empirical information for international marketers about the relationship between the perception of innovation by customers and behavioral intentions and satisfaction. This paper contributes to the growing body of innovation management and adoption of innovation. 


\section{REFERENCES}

Alexandris, Konstantinos, Dimitriadis, Nikos and Markata, Dimitra (2002), Can Perceptions of Service Quality Predict Behavioral Intentions? An Exploratory Study in the Hotel Sector in Greece, Managing Service Quality, 12(4), pp. 224-231.

Allaway, Arthur W. and Berkowitz, David (2005), Modeling Market Adoption of a Retail Innovation over Time and Space, The Business Review, Cambridge, 4(1), pp.13-25.

Arasta Alışveriş Merkezleri ve Perakende Sektörü Dergisi (2006), 31(Temmuz-Ağustos).

Bagozzi, R.P. and Yi, Y. (1988), On the Evaluation of Structural Equation Models, Journal of the Academy of Marketing Science, 16, pp. 74-94.

Baker, Kathryn A. (2002), Communication, Management Benchmark Study, Center for Strategic Leadership Studies, USA.

Baker D.A. and Crompton, J.L. (2000), Quality, Satisfaction and Behavioral Intentions, Annals of Tourism Research, 27(3), pp. 785-804.

Bass, Frank M. (1969), A New Product Growth Model for Consumer Durables, Management Science, 15(January), pp. 215-27.

Bass, Frank M., Krishnan, Trichy V., and Jain, Dipak (1994), Why the Bass Model Fits without Decision Variables, Marketing Science, 13, pp.203-223.

Bearden, W. O. and Teel, J.E. (1983), Selected Determinants of Consumer Satisfaction and Complaint Reports, Journal of Marketing Research, 20(1), pp. 21-28.

Bitner, M.J. (1990), Evaluating Service Encounters' Effects of Physical Surroundings and Employee Responses, Journal of Marketing, 54(April), pp. 6982.

Bloemer, J., de Ruyter, K., and Wetzels, M. (1999), Linking Perceived Service Quality and Service Loyalty: A Multi-Dimensional Perspective, European Journal of Marketing, 33, pp. 1082-1106.

Bolton, R.N. and Drew, J.H. (1991), A Multistage Model of Customers' Assessments of Service Quality and Value, Journal of Consumer Research, 17(March), pp. $375-384$.

Boulding, William, Kalra, Ajay, Staelin, Richard, and
Zeithaml, Valarie A. (1993), A Dynamic Process Model of Service Quality: From Expectations to Behavioral Intentions, Journal of Marketing Research, 30(February), pp. 7-27.

Brady, Michael K. and Robertson, Christopher J. (1999), An Exploratory Study of Service Value in the United States and Ecuador, International Journal of Service Industry Management, 10(5), 469-486.

Burns, Tom and Stalker, George M. (1961), The Management of Innovation, Tavistock, London.

Chatterjee, R. and Eliashberg, J. (1990), The Innovation Diffusion Process in the Heterogeneous Population: A Micromodelling Approach, Management Science, 36, pp. 1057-1079.

Christensen, C.M. (1997), The Innovator's Dilemma, Harvard Business School Press, Boston.

Clark, Ronald A. and Goldsmith, Ronald E. (2006), Interpersonal Influence and Consumer Innovativeness, International Journal of Consumer Studies, 30(1), pp. 34-43.

Cronin, J.J. and Taylor, S.A. (1992), Measuring Service Quality: A Reexamination and Extension, Journal of Marketing, 56(3), pp. 55-68.

Cronin, J.J., Brady, M.K., Brand, R.R., Hightower, R., and Shemwell, D.J. (1997), A Cross-Sectional Test of the Effect and Conceptualization of Service Value, Journal of Services Marketing, 11(6), pp. 375-391.

Davies, Ross (1998), Innovations in the Retail Sector: A Double Edged Sword?, $11^{\text {th }}$ European Retailing Seminar at Templeton College, issue 19, Oxford.

Eggert, Andreas and Ulaga, Wofgang (2002), Customer Perceived Value: A Substitute for Satisfaction in Business Markets, Journal of Business and Industrial Marketing, 17(2/3), pp. 107-118.

Elçi, Şirin (2006), İnovasyon. Kalkınma ve Rekabetin Anahtarı: 5. baskı, Türkiye Bilişim Derneği.

Fell, D.R., Hansen, E.N., and Becker, B.W. (2003), Measuring Innovativeness for the Adoption of Industrial Products, Industrial Marketing Management, 32(4), pp. 347-353.

Fornell, C. and Larcker, D. (1981), Evaluating Structural Equation Models with Unobservable Variables and Measurement Error, Journal of Marketing Research, 18, pp. 39-50. 
Fourt, Louis A. and Woodlock, Joseph W. (1960), Early Prediction of Market Success for New Grocery Products, Journal of Marketing, 25(2), pp. 31-38.

Galbraith, John K. and Holton, Richard H. (1955), Marketing Efficiency in Puerto Rico, Cambridge, Mass: Harvard University Press.

Gerbing, D. W. and Anderson, J. C. (1988), An Updated Paradigm for Scale Development Incorporating Unidimensionality and Its Assessment, Journal of Marketing Research, 15, pp. 186-192.

Goldsmith, R.E. and Hofacker, C.F. (1991), Measuring Consumer Innovativeness, Journal of the Academy of Marketing Science, 19(3), pp .209-221.

Green, R.T. and Langeard, E. (1975), A Cross-National Comparison of Consumer Habits and Innovator Characteristics, Journal of Marketing, 39, pp. 34-41.

Hagen, James M. (2002), Causes and Consequences of Food Retailing Innovation in Developing Countries: Supermarkets in Vietnam, Working Paper presented at the Annual Meetings of the Western Coordinating Committee \#72, Las Vegas, Nevada.

Hamel, Gary (1996), Strategy as Revolution, Harvard Business Review, (July-August), pp. 69-82.

Hamel, Gary and Prahalad, C.K. (1994), Competing for the Future, Harvard Business Review (July-August), pp. 122-28.

Hertog, Pim Den and Brouwer, Erik (2000), Innovation Indicators for the Retailing Industry: A Meso

Perspective, SIID Project Phase 2, Dialogic, Utrecht.

Heskett, J. L., W. E. Sasser Jr, et al. (1997), The Service Profit Chain: How Leading Companies Link Profit and Growth to Loyalty, Satisfaction, and Value, Free Press, New York.

Hirunyawipada, T and Paswan, A.K. (2006), Consumer Innovativeness and Perceived Risk: Implications for High Technology Product Adoption, Journal of Consumer Marketing, 23(4), pp. 182-198.

Hull, F.M. and Hage, J. (1982), Organizing for Innovation: Beyond the Burns and Stalker's Organic Type, Sociology, 16(4), pp. 564-577. 